\title{
AUTHORITY AND BUREAUCRACY FROM WEBER'S PERSPECTIVE
}

\section{WEBER'IN BAKIS ACYSINDAN OTORITE VE BÜROKRASI}

\author{
Vedat YILMAZ ${ }^{1}$, Cüneyt TELSAÇ²
}

1. Assoc.Prof., Van Yüzüncü Y1l University, Faculty of Economics and Administrative Sciences, vedatyilmaz1977@gmail.com, https://orcid.org/0000-0003-4624-9824

2. Independent Researcher, cuneyttelsac@gmail.com https://orcid.org/0000-0002-4133-4846

$\begin{gathered}\text { Makale Türü } \\ \text { Derleme }\end{gathered}$
Article Type
Review Article
26.03.2021
Yayırua Kabul Tarihi/Acceptance Date
15.04 .2021
DOI
10.20875/makusobed.903546

Y1lmaz, V. ve Telsaç, C. (2021). Authority and bureaucracy from Weber's perspective. MAKU SOBED, (34), 42-52.

https://doi.org/10.20875/makusobed.903546

\begin{abstract}
The first name that the bureaucracy concept evokes today is undoubtedly Max Weber. In Weber's management theory; there are three types of authority, which Weber tries to question why people obey orders. Weber; states that these authorities, which he describes as traditional, charismatic, and legal-rational models, can all provide obedience, but each will suit a different stage in the development of organizations. This study aims to reveal the meaning that Weber attributes to the concept of authority trilogy and bureaucracy. As a method, a literature review has been made. The findings obtained have been analyzed with a critical point of view and in detail and content analysis and interpretation techniques have been used to examine the findings. Also including the ideas of the leading thinkers of the Islamic world on the issues of authority and legitimacy has enriched the article.

Keywords: Max Weber, Bureaucracy, Rational Authority, Officialdom.

Öz

Bürokrasi kavramının bugün çağrıştırdığ 1 ilk isim şüphesiz Max Weber'dir. Weber'in yönetim teorisinde; insanların neden emirlere uyduğunu sorgulamaya çalıştığı üç tür otorite vardır. Weber; geleneksel, karizmatik ve yasal-rasyonel modeller olarak tanımladığ $1 \mathrm{bu}$ otoritelerin hepsinin itaat sağlayabileceğini, ancak her birinin örgütlerin gelişiminde farklı bir aşamaya uygun olacağını belirtiyor. Bu çalışma, Weber'in otorite üçlemesi ve bürokrasi kavramına yüklediği anlamı ortaya çıkarmayı amaçlamaktadır. Yöntem olarak literatür taraması yapılmıştır. Elde edilen bulgular eleștirel bir bakıș açısıyla ve detaylı bir șekilde analiz edilmiş ve bulguların incelenmesinde içerik analizi ve yorumlama teknikleri kullanılmıştır. İslam dünyasının önde gelen düşünürlerinin yetki ve meşruiyet meselelerindeki fikirlerine de yer verilmesi ayrıca makaleyi zenginleştirmiştir.
\end{abstract}

Anahtar Kelimeler: Max Weber, Bürokrasi, Rasyonel Otorite, Memuriyet. 


\section{GENIŞLETILMIŞ ÖZET}

Günümüzde bürokrasi kavramının ilk çağrıștırdığı isim hiç şüphesiz Max Weber'dir. Weber Birinci Dünya Savaşı ve öncesinde Freiburg, Heidlberg ve Münih Üniversitelerinde ders vermiş dünyaca ünlü bir sosyologdur. Modern anayasal-yasal çerçeve dâhilinde kurumsallaşmış bir rızaya bağlı uzlaşıyı öngören bu anlayış günümüzde pek çok büyük ölçekli şirket ve kurumda uygulanma alanı bulmaya devam etmektedir. Weber' in hukuki meşruiyet teorisinin en iyi betimlemesi yasal-ussal bürokrasi modelinde vücut bulmuştur.

Klasik kamu yönetiminin ön gördüğü güçlü devlet yapısı; çoğunlukla Weber'in kavram haline getirdiği bürokrasi modeli temelinde örgütlenme yoluna gitmiştir. Yönetim alanında yarattığı etki yadsınamaz ölçüde büyüktür. Weber'in bürokrasi modeli, dönemin yönetim yapısına büyük ölçüde katkı sunmuştur. Weber bürokrasiyi bir kavram olarak, ilk kez geniş ve sistemli bir şekilde inceleyen teorisyendir. Weber bürokrasi için; alanında uzman sayılan birçok insanın belli bir işlevi yerine getirmek açısından yaptıkları işbirliğinin örgütlü şekilde devam ettirilmesi tanımlamasını yapar. Weber bürokrasiyi ele alırken bunun bir örgütlenme ve yönetim biçimi olduğunu vurgular. Bürokrasi teorisinin özünü; Weber'in egemenlik ve meşruluk hakkındaki fikirlerinin oluşturduğunu da belirtmek gerekir. Egemenlik ve meşruluk fikirlerinden yola çıkarak bürokrasiyi kavramsallaştırır.

Weber'in yönetim teorisinde; insanların neden emirlere uyduğunu sorgulamaya çalıştığı üç tür otorite vardır. Weber; geleneksel, karizmatik ve yasal-ussal model şeklinde belirttiği bu otoritelerin, tamamının itaati sağlayabileceğini fakat her birinin organizasyonların gelişiminde farklı bir aşamaya uygun düşeceğini ifade eder. Bu üçlemeden yasal-ussal otoritenin en etkili yöntem olduğunu, sıkı bir bürokratik idarede; kesinlik, hız, sürdürülebilirlik, gayrişahsilik ve itaatin en ideal noktaya ulaşacağını belirtir. Weber örgüt yapısı ve işlevleri temelinde yürüttüğü çalışmaların bir neticesi olan bürokrasi modeli için "ideal tip" tanımını kullanır. Tanıma göre; bu yolla var olan örgütlerin bürokratikleşebilmesi bu ideal tipe ne kadar yaklaşabildikleriyle doğrudan ilişkilidir.

Weber örgüt yapısı ve işlevleri temelinde yürüttüğü çalışmaların bir neticesi olan bürokrasi modeli için "ideal tip" tanımını kullanır. Bu tanıma göre bu yolla var olan örgütlerin bürokratikleşebilmesi bu ideal tipe ne kadar yaklaşabildikleriyle doğrudan ilişkilidir. Weber'in bu noktada "ideal" kelimesinden kastı "arzulanan", "iyi", "üstün" anlamında değildir. Bu kavramla anlatılmak istenen şey bir şekle benzetilebilir. Örgütler bu ideal tipe yaklaşabildikleri ölçüde bürokratikleşebilirler.

Weber öncelikle "İnsanlar niçin itaat ederler?" sorusunu mantıklı bir zeminde açıklamaya gayret etmiştir. Mevcut İnsanların kendi aralarındaki boyun eğme koşullarını ve şekillerini gözlemlemiştir. Weber açısından otorite emirlerin yerine getirilmesini sağlayan etkendir. Tam bu noktada meşruluk tanımı, bu otoritenin kendisine boyun eğilmesini sağlayan unsurlardır. Weber tarafından dile getirilen otorite kavramı bu ikisinin birleşmesinden oluşur. Weber, siyaset ve yönetim dünyasında iktidarı elinde tutan otoritenin emirlerine uyanların, bunu neden yaptıklarını, tarihsel ve sosyal gelişmeleri göz ardı etmeden ele aldığı otorite üçlemesiyle dile getirmiştir.

Weber, belirttiği otorite tipleri arasındaki temel farklılı̆̆ın sebebini; sosyal yapı özelliklerine ve bunların ekonomik önemlerine bağlar. Özellikle vurguladığı; bu yaklaşım türlerinin kullanılabilinecek tek yaklaşım olmadığı ve bu tür uygulamalardaki bütün hâkimiyet yapılarının mutlaka bu saf tiplerden birine uyması gerekmediği olgusudur. Weber uygulamadaki örneklerin aksine büyük çoğunluğunun bu saf tiplerin bir bileşimi ya da aralarındaki geçiş halini yansıttığını belirtir. Bu durumu sık sık kullanmak zorunda kaldı̆̆ “patrimonyal bürokrasi” gibi deyimler üzerinden açıklamaya çalışır ve bazı olguların karakteristik özelliklerinin kısmen akılcı hâkimiyete, bazılarının ise gelenekçi hâkimiyet tiplerine ait olduğunu söyler bunun yansıra tarih boyunca her yana yayılmış Feodal hâkimiyet yapısı gibi önemli tiplerin de görmezden gelinemeyeceğini belirtir. Hemen hemen tüm büyük ölçekli büro ve organizasyonlarda kaçınılmaz bir şekilde bürokrasiyi görmek mümkündür. Siyaset ve yönetimi birbirinden ayırmanın mümkün olmadığ1 gerçeği bizi sürekli yönetim türlerini incelemeye götürmektedir. Bürokrasinin siyasetle kesiştiği pek çok alan bizim "İktidar kimde?" sorusunu sormamıza sebep olmaktadır.

$\mathrm{Bu}$ çalışma, Weber'in otorite üçlemesi ve bürokrasi kavramına yüklediği anlamı ortaya çıkarmayı amaçlamaktadır. Ayrıca makalenin özgünlüğünü ise; otorite, meşruluk ve memurluk mesleğine ilişkin İslam dünyasının önde gelen düşünür ve filozoflarının da fikirlerine yer yer başvurulması oluşturulmaktadır. Gelişen ve değişen dünyamıza rağmen; otorite, meşruiyet ve itaat kavramlarının güncelliği hep korunagelmektedir. Gündemdeki yerini hiçbir zaman kaybetmeyen bürokrasinin, birçok ofis ve kuruluş tarafindan uygulanmaya devam edilen en yaygın yönetim şekli olması da; ayrıca bir ilgiyi hak etmektedir.

Yöntem olarak literatür taraması yapılmıştır. Bununla birlikte, çalışmaya esas teşkil eden eserler düşünürlerin kendi eserleri olmuştur. Elde edilen bulgular eleştirel bir bakış açısıyla ve etraflıca incelenmiştir. Bulguların incelenmesinde içerik analizi ve yorumlama teknikleri kullanılmıştır. Ulaşılan kanıya göre, bürokrasilerin; sorumluluk almama eğilimi ve bu sebepten ortaya çıkan kırtasiyecilik ve işlerin gecikmesi, değişen şartlara ve ihtiyaçlara uyum sağlanamaması, aşırı formel ve şekilci yapısı, zamanla örgüt içerisinde oluşan büro dayanışması, hiyerarşide üst konumda bulunan yöneticilerin altta bulunan uzman personele bağımlı hale gelebilmesi gibi kronik sorunları göz ardı etmemekle beraber "Birlikte nasıl daha iyi yaşayabiliriz?" sorusunun cevabını sorgulamak gerekmektedir. 


\section{INTRODUCTION}

Today, the name Weber seems to be integrated with the concept of bureaucracy. The impact created in the field of management is undeniably large. In Weber's management theory; there are three types of authority, which people try to question why people obey orders. Weber; states that these authorities, which he describes as traditional, charismatic, and legal-rational models, can all provide obedience, but each will suit a different stage in the development of organizations. From this trilogy, it is stated that legal-rational authority is the most effective method, and in a strict bureaucratic administration; he states that precision, speed, sustainability, impersonal, and obedience will reach the ideal point. Weber uses the definition of "ideal type" for the bureaucracy model, which is a result of his studies on the basis of organizational structure and functions. According to the definition; the bureaucratization of existing organizations in this way is directly related to how close they can get to this ideal type.

Weber is a world-renowned sociologist who taught at the universities of Freiburg, Heidelberg, and Munich before and during the First World War (Hindle, 2012, p. 468). The best description of Weber's legal legitimacy theory is embodied in the Legal-Rational Bureaucracy model. This understanding, which foresees an institutionalized consensus within the modern constitutional-legal framework, continues to find application in many large-scale companies and institutions today (Mccormick, 2015, p. 14; Kocakula, 2020, p. 249). This bureaucracy model, which is based on rational foundations, is a structure based on authority and hierarchy, progressing within the framework of written rules, in which division of labor is made, especially in the form of an impersonal organization.

Strong state structure envisaged by classical public administration; it mostly organized on the basis of the bureaucracy model that Weber made a concept. Weber's bureaucracy model contributed greatly to the management structure of the period (İzci et al, 2020, p. 72; Y1lmaz and Efşan, 2019, p. 343). Weber is the theorist who first studied bureaucracy as a concept in a broad and systematic manner. The Weber bureaucracy; defines continuing the cooperation of many people who are considered experts in their field in order to fulfill a certain function. The name of Weber is almost integrated with bureaucracy (Ery1lmaz, 2016, p. 45; Merton, 2016, p. 128; Akar, 2018, p. 484). The bureaucracy model is based on detailed rules and formalism. While Weber deals with bureaucracy, he emphasizes that it is a form of organization and management (Mecek and Kocakula 2020, p. 1421). The essence of the bureaucracy theory, forms on Weber's ideas about sovereignty and legitimacy. It conceptualizes bureaucracy based on the ideas of sovereignty and legitimacy (Dursun, 1992, p. 135; Merton, 2016, p. 128).

Weber uses the definition of "ideal type" for the bureaucracy model, which is a result of his studies on the basis of organizational structure and functions. According to this definition, the bureaucratization of existing organizations in this way is directly related to how close they can get to this ideal type (Erylmaz, 2016, p. 267; Akçakaya, 2016, p. 676). Weber's word "ideal" at this point does not mean "desired", "good", "superior", and what is meant to be explained with this concept is compared to a shape so organizations can become bureaucratized to the extent that they approach.

Weber firstly tries to explain the question "why do people obey" on a logical ground. He observes the conditions and forms of submission of the present humans among themselves. For Weber, authority is the factor in the execution of orders. At this point, the definition of legitimacy is that the authority elements that make this submissive to itself. The concept of authority expressed by Weber consists of the combination of these two (Öztaş, 2015, p. 148). Weber questioned why people obey the orders of the authority holding the power in his authority trilogy without ignoring historical and social developments.

This study aims to reveal the meaning that Weber attributes to the concept of authority trilogy and bureaucracy. The importance of this article stems from the fact that the concept of bureaucracy, which has never lost its place on the agenda, is still the most common form of management that many offices and organizations continue to implement.

\section{AUTHORITY ACCORDING TO WEBER}

While Weber evaluates authority as the power of command, he says that this concept is a social event and is a sociological fact rather than a juristical one, and even emphasizes that its use is in the form of social authority. He says that the orders given to him for authority will be valid if he feels as if they are his own usual behavior. Weber uses the terms "autoritat" (authority) and "herrchaft" (sovereignty, power) for 
authority. The concept that should be preferred in terms of being suitable for the purpose is "herrchaft", because this word represents more the emphasis on sovereignty in German and the expressions that will make the definition better understood can be stated as follows (Tortop, et al., 2016, p. 427):

- Existence of a sovereign person or persons,

- People who exist under the sovereign yoke,

- Presence of orders or orders for people who are under the yoke of sovereignty,

- Obeying orders,

- Those who obey orders see the implementation of these orders as their normal behavior.

\subsection{Types of Authority}

Weber regards three interior reasons for ideal sovereignty as legitimate. Apart from the existing legal meaning of the concept of legitimacy, it evaluates it as a more comprehensive and essentially social fact. Based on this, legitimacy; forms the basis of sovereignty. For Weber, there is an opinion that no illegitimate sovereignty can be permanent (Tortop et al., 2016, p. 428). For Weber, there are three pure forms of authority. These we can list it as a charismatic, traditional, and rational-legal authority (Weber, 1987, p. 81; Weber, 2014, pp. 52-54; Weber, 2018, pp. 77-80).

1. Traditional Authority: The authority of the eternal past, that is the traditions and customs that are applied so old that it is not known when it belongs to and the acceptance culture is sanctified. The sacredness of traditions and the natural legitimacy of those who exercise their authority under these traditions are accepted (Weber, 1987, p. 81; Weber, 1987, p. 52). It is the type of sovereignty that takes its power and legitimacy from tradition. Its primitive form is expressed as "Geontocracy", "the sovereignty of the oldest of the family" and Patriarchalism (Patriarchal) family. Traditions determine the nature and boundaries of the sovereignty in question. In order to maintain this traditional sovereignty, the Patrimonial leader must appoint relatives and those close to him as officers. Weber defines this system as Sultanism (Özer and Önen, 2017, pp. 43-44). According to Weber, the most important legitimacy source of tradition-based authority is patriarchalism. Depending on the development process of the society in question, Geontocracy can take on a larger-scale structure in the form of Patriarchalism, Patrimonialism, and sultanism.

2. Charismatic authority: The authority of the extraordinary and god-given personality (charisma) is a form of authority based on absolute devotion and trust to a particular person and his superior qualities (Weber, 1987, p. 81; Weber, 2014, p. 53). It has an acquired structure. Because, like traditional authority, it takes its power from the superior abilities of a person, not from inborn and tradition. Because this authority is fed from a sociological infrastructure (Ery1lmaz, 2016, p. 273). The source of sovereignty is the leader's personal behavior, attitude, and beliefs. All this is due to the power given to him by God. These are not open to criticism and must be accepted as they are (Özer and Önen 2017, p. 43; Weber, 1987, p. 81). In Gazzali's (AD 1111) book titled Nasihatü'l-Mülük (Yazar, 2020, p. 229): "He accepts the administration as the blessing of Allah and says that the rulers are the people chosen by Allah to increase the welfare of the people and order the world affairs." $\mathrm{He}$ states that rulers are "Zillulah fi'l-Arz", that is, the shadow of Allah on earth, and obedience is obligatory because Allah has chosen them. The fact that the ruler was sent by Allah should not be forgotten. For this reason, it should be obeyed, loved, followed and not opposed to it ". What Gazzali tries to express with these sentences is the concept of "ferr-i izadi". About Ferri izadi, he associates the light coming from Allah with the concepts of truth, whose source is divine, and charisma, which is a natural outcome of it. He is the "ferri divine" person who carries the light and power of Allah on him. Obedience to these people who carry the light of Allah also means obedience to Allah.

3. Rational-Legal Authority: It is a type of sovereignty based on the legitimacy of the individuals and laws elected in accordance with rationally established laws. Orders given according to this form of authority are legal and therefore people obey this because orders have a legitimate and rational nature (Özer and Önen 2017, p. 44). Obedience is essential in fulfilling the duties determined by law (Weber, 1987, p. 81). Weber argues that rational-legal authority is legitimate because he points out the best example of the rule of law as the rationality of law that we see in parliamentary governments. (Mccormick, 2015, p. 25). It is a type of authority based on law. It depends on the "belief" created by the rational and functional use of authority. (Eryılmaz, 2016, p. 273). This authority is acquired as a result of choices made by reason and logic and is transferred in the same way. Rules are binding for everyone. This authority provides the basis for more specific and more 
universal bureaucratic structures. Rational rules are equivalent to law. At this point, the bureaucracy predicted by Weber represents the most developed form of legal authority.

4. Ibn Khaldun states in his work titled Muqaddima about the necessity and importance of law: The ruler must establish laws that are just and everyone can obey. He states that the people will obey only within the political laws that protect the rule of law and that legitimate sovereignty can be obtained by means of this. At the same time, it says that the world life and the hereafter can be happy only with the laws that Allah has made (Haldun, 2016, pp. 41-42). In the work of Ebü'n Necip Şeyzeri, in which we saw a similar approach, named Nehcü's-Sülük Fi Siyaseti'l- Mülük (political strategies); He states that the need of the people for a just, compassionate and virtuous ruler is more than the need for the rain of the people of the region, who suffered from thirst due to the scarcity of rain. He explains it as follows; the people need rain, but a good ruler is always needed (Seyzeri, 2013, p. 69).

Weber explains the social structure features in society and their economic value as the reason for the fundamental difference between authority types. Especially emphasized; the fact is that these types of approaches are not the only ones that can be used and that all dominance structures in such applications do not necessarily fit one of these pure types. Weber states that unlike the examples in practice, the vast majority reflect a combination of these pure types or the transition state between them. He tries to explain this situation through idioms such as "patrimonial bureaucracy" that he has to use frequently and says that the characteristic features of some phenomena belong partly to rational dominance and some of them to traditional types of domination. He also states that important types such as the feudal domination structure that have spread throughout history cannot be ignored.

\section{BUREAUCRACY ACCORDING TO WEBER}

Weber defines bureaucracy as the continuous organization of cooperation between a large number of individuals, each of whom is specialized and performing a function (Heper, 1996, p. 293). Weber's bureaucracy model is associated with legal authority, which is one of the types of authority it puts forward. This type of authority is defined as 'bureaucratic authority'. He stated that the most reasonable type of authority in terms of bureaucracies should be a legal authority as follows (Weber, 1987, p. 81; Y1ldiz and Günay, 2020, p. 201). The legal authority for Weber (1987, p. 81):

- Provides managerial continuity.

- Those who work in managerial positions are recruited according to their abilities and merits.

- Legal basis and arguments that they can use are presented to the managers in terms of using their powers.

- The content and boundaries for this authority are clearly and clearly drawn.

As for authority holders, those in power must have a staff to have an effective role in the relations between the rulers and those who are ruled and to implement their orders. Weber has named this staff "executive general staff -verwaltungis-tab" to implement the orders of the authority holders. When considered in a broad sense, this concept is similar to the word "administration." Based on this concept, for the administration we can say as follows: It consists of a staff that will fulfill the orders given by those who hold the authority. It is not possible to ensure the continuity of power without a structure (administration) that will implement the orders of those who hold the authority. The administration appears as a structure consisting of people and organizations that are accustomed to obeying orders, have interests in obeying orders, support the authority to use the power of orders and legitimate coercion, and stand ready to fulfill the duties assigned to them in this regard (Doğan, 2020, p. 415; Dursun, 1992, p. 138). It accepts the society as an organic whole and reflects the society as a great sum of functions (Acar, 2018, p. 674). Weber's view at this point evokes a method whose examples we have seen throughout history. The organismist understanding of society applied by both Plato and Aristo, as well as Ghazali and Farabi, is a metaphor that is frequently used in Islamic philosophy and Islamic societies, especially after Farabi (Akbal, 2020, p. 85). For example, Farabi (AD 870-950), in chapter 17 of his work named Mabadi Ara Ahl al-madina al-Fadıla (Ideal State), tried to describe society by likening it to a living organism, that is, the human body. Farabi states that the first organ to be formed is the heart, therefore it undertakes the most important task, and that the other organs close to the heart undertake less important tasks due to their nature, and that the organs under them perform the lowest tasks. In this case: Those who are close to the ruler of the city perform the most honorable voluntary acts, those below them perform less honorable voluntary acts, and thus those who do voluntary 
acts of the lowest kind are reached (Farabi, 2016, pp. 101-102). Farabi describes this hierarchical structure as follows: "The heart, which is the most perfect of all organs in terms of its special features; just as he commands the organs below him, all the other organs are in the position of the supervisor of the one that is lower than it in terms of degree". (Akbal, 2020: 87-88; Farabi, 2016, pp. 101-102). For this organismist approach seen in Farabi's work, it is possible to see that many Islamic thinkers who wrote works about the administration and the state in the tenth century when this work was written and in the recent period following it, tried to explain the administrative structure through such analogies.

While the governing body discussed in Fârâbî's work, that is, the first president, is the prophetphilosopher at the top in the virtuous state administration, however, for Ibn Rushd's views this situation is similar to Plato's views about philosophers. In this respect, it is sufficient to have philosophers who have learned the knowledge of theoretical and practical sciences. When considered in terms of the philosopher being a prophet, it is seen that Ibn Rushd thinks differently from Farabi on this issue and positions the leadership within the worldly limits within his own conditions (Rüşd, 2011, pp. 127-128). According to one of the Islamic thinkers, Kindi, revelation coming to the prophet is divine and its source is Allah; whereas philosophy is a human product and human art, and its source is human. Though like this, he regards and evaluates the best of human arts in terms of value and rank as the art of philosophy (Kindi, 2013, p. 126).

Weber divides bureaucracy into rational and patrimonial. For the patrimonial bureaucracy, It is an administrative structure formed by the servants in captivity where the slavery system is widespread. In such organizations, individuality, kinship ties, inherited values, and especially status are dominant features. Weber shows Ancient Egypt, the Roman Empire, and the Byzantine Empire as examples of such patrimonial bureaucracies. Weber states that the instability of such bureaucracies is due to the absence of a developed money economy and the non-implementation of the principle of impersonalism (Doğan, 2020, p. 416; Eryllmaz, 2016, pp. 269-270; Weber, 1987, p. 200).

Weber defines rational bureaucracy as impersonalism, rationality, administrative regulations, and the modern structure and mode of operation protected by laws. The benchmarks that the officer will take as a basis in terms of loyalty are official rules and official goals. According to Weber, personnel are officers who come to work upon appointment and the officer who comes with an assignment will be more successful and sensitive technically.

\subsection{Features of Bureaucracy}

Weber states the features of contemporary bureaucracy as follows (Telsaç, 2020, p. 22; Weber, 2016, pp. 55-58; Weber, 1987, pp. 192-194):

1. There are some general rules in bureaucracy. These rules are determined by laws and regulations. These rules are official and valid in a specific scope of authority. These rules are:

- In order for the organization to achieve its goals, regular functions are divided into official duties,

- The authority to give orders has been shared in a balanced way in order to fulfill the specified duties,

- It is the use of the authorities by taking systematic decisions in order to continue the duties regularly and continuously with the employment of personnel with certain qualifications.

- There is a clearly defined sub-superior relations system, in this way, it is aimed that top managers can supervise the lower-level employees. The existence of hierarchical powers is seen in all bureaucratic organizations.

2. Modern bureaucracies rely on written documents. As bureaucracies evolve, private life and official activities are strictly separated.

3. Personnel working in both private enterprises and public institutions should have good specialist training in their field and should also have improved themselves.

4. Staff working in contemporary bureaucratic organizations should use all their capacities for the benefit of the organization.

5. In bureaucratic organizations, training of managers in the field of public administration, law, and business management will be beneficial in terms of stability and scope.

Weber stated the advantages of rational bureaucracy as follows (Ery1lmaz, 2016, p. 270; Weber, 1987, pp. 205-209): 
- Fully bureaucratized organizations can reach the highest technically efficient level. Bureaucratic structures are effective and efficient structures.

- Bureaucracy is the most ideal form of organization for both the state and the private sector.

- Bureaucratic organization is a very important force. It provides an important advantage for those who hold this power. Bureaucracy derives its strength from reliability, expertise, rationality, and continuity.

\subsection{Officer Position According to Weber}

According to Weber, the personal position of the officer is guaranteed in accordance with his social status and hierarchical structure. Places where the social reputation of officers is weak; are places where there is little need for the management of experts and where status traditions do not prevail.

The position of the officers is inherently like a task and the officers have job security. The officer normally works in the institution until his retirement (Weber, 1987, pp. 193-194). Weber's ideas on the officers are the logical consequences of bureaucracy principles (Hughes, 2014, p. 108). Weber specifies the position of a bureaucratic official with the following clauses (Weber, 1987, pp. 194-199, Weber, 2016, pp. 59-63):

1. Officers, whether in the private or public sector, always strive, and often do, to gain a more respected place in society compared to the managed one. Thanks to the rules determined by the hierarchical order, the social position of the officer is preserved. Reputation management means continuity in this respect, it is a continuous activity (İzci et al, 2019, pp. 310). Weber states the high de facto social position of the officers in the former civilized countries and the conditions for this to continue as follows (Weber, 2016, p. 59):

- There is a strong demand for an executive management staff with trained experts,

- Officers generally come from socially and economically privileged strata,

- Required training costs are binding for the officers,

- Finally, he attributes it to the existence of a strong and stable social segregation in society.

As an example, Eryllmaz recounts the position of officers in the Ottoman Empire as follows (Eryilmaz, 2016, pp. 231-232): What was expected of wealthy people was that they would make a foundation. Since the source of wealth was mostly the official duty, the majority of those who made the foundation works were primarily the sultans and other public officials.

Weber states that having professional qualifications and the necessary certificate licenses will increase the "status power" of social position. But he argues that this only applies in isolated cases. Usually, recruitment is done with the consent of the employers. He points out the German army as an example. He likens the guild-type structures that encourage officials to be held behind closed doors to the patrimonial bureaucracies of the past, and he says that especially the office of the priesthood is an example (Weber, 1987, p. 197).

2. Recruitment of officers must be done through a professional license, diploma, and special exams. In theory, a bureaucratic official is appointed by a higher official. An official elected by the ruled is theoretically not an official. In any case, the selection of officials by the electorate softens the rigidity of hierarchical dependence. What softens the rigidity of hierarchical dependence is the selection of officials among the ruled. This method will allow the officer to have an autonomous position vis-à-vis his superiors. Naturally, the selection of officials will in any case be based on one's service and loyalty to the party or party chairman, not on the basis of expertise or merit. In places where there is a high-level, freely determined public opinion, and party supporters demand an intellectually developed and specialized management, bringing unqualified people to work will have a negative effect on the next elections in terms of power (Weber, 1987, pp. 195-196). Today, there is a demand for an administration with specialist training in the United States, but it is not possible to say that a conscious public has been formed in states where immigrant votes are controlled as a block. For this reason, the determination of senior managers and their assistants in general elections; prevents both the competence of the person to be appointed and the correct functioning of the bureaucracy mechanism. It also weakens the staff's dependence on hierarchy. Weber points to that in the United States, federal judges appointed by the president himself are known to be more reliable and more qualified than elected judges. On the other hand, he indicate that the mayors who carried out major reforms in the United States did this both by elections and by working with a group of officials they appointed, and 
that these reforms were made in a "caesarist (despot)" manner. It is based on the assumption that Caesarism, which is a technically organized and powerful form of authority, generally develops within democracy and that it is the representative of large masses (army and people) who often do not care about traditions (Weber, 1987, p. 197). However, he considers the suzerainty of individual intelligence contrary to the universal democratic principle. Anthony Downs in his 1967 article Life Cycle of Offices: "If managers with key functions in an office are of a similar nature and view, then the behavior of the bureau and the bureau can be shaped around this view. The possibility that a few people dominate all the activities, causes the power to gather at the top in terms of hierarchical structure." (Downs, 2016, p. 348).

3. Officialdom is based on the principle that the officer is employed for life. Partial independence position guaranteed by law, thanks to job security stipulated by the bureaucracy; provides assurance to the officer. It ensures that only in places where legal guarantees are set in order to prevent displacement and dismissal for personal reasons, certain officialdom duties are implemented in an absolutely objective manner free from personal concerns that may occur. First of all, there is a similar picture in terms of judicial officers and increasingly, all other administrators (Weber, 1987, p. 198). A similar approach to this can be seen in the Koçi Bey Treatises, which were prepared long ago (AD 1631). For this situation, Koçi Bey point to, in his treatise presented to VI. Murat Han (Seventeenth Ottoman Sultan); states that "A public official would not be dismissed from his duty unless he had a crime and sin, especially since sancakbeyi and beylerbeyi (senior official) would continue their duties in the same office for twenty or thirty years." accordingly so states the necessity of long-term employment of the officialdom (Kurt, 2018, p. 43). At the same time, he gives advice on how to improve the state administration with this view and he states that the sheikh al-Islam Sunullah Efendi was dismissed several times for no reason. So that he draws attention the newly arrived officials were afraid of being dismissed, and for this reason, they had to show false friendship towards the statesmen about fearing being dismissed (Kurt, 2018, p. 61).

4. There are social benefits such as the old age security provided by the pension that officers have, as well as a regular salary. The said wages are determined not according to the job performed, but according to the hierarchical position of the employee, that is, the status (rank) and the time he has been in the post. The fixed incomes of the civil servants, combined with their social dignity, made them a sought-after position, especially in countries that could no longer generate colonial profits. However, on the other hand, this situation caused the officer wages in those countries to remain at a low level. (Weber, 2016, p. 63; Weber, 1987, p. 199). We see that unwillingness and indifference appear in employees who often think that their wages are insufficient (Telsaç, 2019, p. 19). When the happiness of the employees is realized, the integration with the organization is ensured (Telsaç, 2018, p. 29). In couplet 2970 and 2972 of Yusuf Has Hacib's Kutadgu Bilig, written in the 10th century one of the subjects he touched on advising how the ruler should behave to the to employees: "The mürüvvet (generosity) is a sect and so if he does not treat the ruler servants with fairly, it means that this sect would disappear" (Hacib, 2017, p. 230-231; Özçınar 2020, p. 312).

5. There is a career system in the bureaucratic hierarchy and officers strive to build a career in this system. There is a trend from relatively fewer prefers and low monthly positions to positions with higher demand. Officer salaries are generally; seniority is organized according to a field of specialization and degrees gained through experience. However, in some cases, limiting the qualifications of the Official and conducting the business with a monopoly may cause the candidates' education diplomas to remain ineffective and insignificant. There is a situation where educational diplomas are not taken into account in the distribution of the highest political duties such as ministerial duties, only personal and intellectual qualifications are taken into account. (Weber, 1987, p. 199). A similar event for the career system is mentioned ten centuries ago by Maverdi in his work entitled Principles Of Administration (AD 975-1058) (Maverdi, 2019, p. 68): "If people do not like the sudden assignment of a competent person to a higher level they will avoid obeying him. It would be more appropriate to raise such a person gradually from the lower levels to the upper levels".

Weber says that for officer working in the public sector, they do not undertake leadership duties and only personal responsibility at the political level is in question and explains that with (Hughes, 2014: 108): "Being passionate about taking a position is above all elements of the political leader. The action of the politician is subject to a principle quite different from the public servant's principle of responsibility, after all, it is its exact opposite. The dignity of the public servant is earned by his ability to carefully carry out the orders of the higher authority as if the orders fully reflect his own needs. Even if the order is contrary to his views this situation is valid and the authority insists on the order even if the public servant objects to the order. At the highest level, without this moral discipline and dedication, the whole system will fall apart. The 
dignity of the political leader lies in the strictly exclusionary personal responsibility for what he does, such a responsibility that the politician cannot (should not refuse) or transfer it (should not transfer)". Weber frequently states the superiority of the political authority in determining how a legal regulation will be (Mccormick, 2015, p. 112).

According to Weber, the important factor that enables the development of bureaucratic structures is that they are always technically superior to other forms of organization. The superiority of a fully developed bureaucratic process is the superiority of a firm producing machinery over all other non-mechanical productions (Weber, 1987, p. 204). Bureaucracy is an effective and efficient organizational system. Organizations with a bureaucratic structure in every aspect can reach the maximum efficiency in terms of technique. Bureaucracy is a unique organizational structure, widely applied not only in the state but also in the private sector. Bureaucracy is a powerful form of organization and its holders have an important source of power. The bureaucratic organization draws its strength from its rationality, expertise, reliability, and continuity.

\section{CONCLUSION AND DISCUSSION}

It is inevitably possible to see bureaucracy in almost all large-scale offices and organizations. The fact that it is not possible to separate politics and administration from each other, its leads us to examine the types of management constantly. On the other hand states that the principles accepted as the universal principles of management such as authority, division of labor, and hierarchy belong to organizations, not to management. In many areas where bureaucracy intersects with politics, we ask "who has the power?". The sources of power held by the bureaucracy are too large to be underestimated. Actually Weber; without prejudice, it acknowledges the fact that increasing bureaucratization may pose a danger to individual freedoms and democratic institutions. So what distinguishes Weber's model from other authorities and bureaucracies? At this point, the understanding of legal-rational authority and the ideal bureaucracy model enlightens us. The acquisition of this type of authority as a result of the choices made by reason and logic and the transfer of it, in the same way, displays a very positive picture when evaluated under today's conditions. Rules are binding for everyone. At the same time, this mandate provides a basis for more specific and more universal bureaucratic structures. Of course, the understanding that rational rules are equivalent to law prevails. Following this, the formal hierarchy based on Weber's career structure; lifelong employment for each employee, selection in technical matters, a fixed salary, and the right to retirement can be updated and maintained under today's conditions. According to Weber official duty is; it should not be seen as a source of rent or profit as it is not of the kind developed against a single person. Official duty is rather an impersonal and demonstrated loyalty to the law. While all these make us view rational bureaucracy positively, but the model put forward based on the transition to a market-based state structure in the 21st century has been very inadequate and helpless in the face of economic globalization and post-national developments. Market-focused, new limited understanding of the state demanding the narrowing of the intervention areas of the state and theories that anticipate the reduction of the public in volume; it reveals the fact that the current structure of the bureaucracy is unsustainable. Bureaucracies have chronic problems such as the tendency not to take responsibility and the delay of paperwork and work that arise due to this reason, the inability to adapt to changing conditions and needs, and overall formalist structure, the office solidarity that has formed. In addition to all these, it should not be overlooked that the top managers in the hierarchy become dependent on the expert staff at the bottom. Despite all this inefficient picture, it should not be forgotten that many offices and organizations in developed countries already have a bureaucratic structure. So the inevitability of bureaucracy is pushing you to seek the answer to this question. "How can we live better together?".

\section{的彩的}

$\mathrm{Bu}$ çalışma, etik kurul izni gerektirmemektedir.

Makale araştırma ve yayın etiğine uygun olarak hazırlanmıştır. Yazarlar arasında herhangi bir çıkar çatışması bulunmamaktadır.

Araştırmanın tüm süreçlerinde araştırmanın yazarları eşit derecede katkı sağlamıştır. 


\section{REFERENCES}

Acar, H. (2018). Kamu güvenliğinin sağlanmasında Weberyen bürokrasi ve hiyerarşi kavramı. Uluslararası Yönetim İktisat ve İşletme Dergisi, 14(3), 667-684. https://doi.org/10.17130/ijmeb.2018343117

Akar, F. (2018). Yeni kamu işletmeciliği paradigmasının türk kamu bürokrasisinde kamu personeli istihdam şekilleri üzerine etkileri. Uluslararası Yönetim Akademisi Dergisi, 1(3), 480-495. https://doi.org/10.33712/mana.499815

Akbal, İ. (2020). Farabi siyasal düşüncesinde toplum, devlet yönetimi ve siyasi rejim sorunu, M. Akıncı, G. N. Şafak. (Eds.). Türk İslam Siyasi Düşüncesi. Kadim Yayınları, 81-107.

Akçakaya, M. (2016). Bürokrasi kuramları ve Türk kamu yönetiminde bürokratik sorunlar, Gazi Üniversitesi Sosyal Bilimler Dergisi, 18(3), 669-694.

Atmaca, Y. and Günay, C. M. (2020). Bürokratik oligarşi: Türk kamu yönetimi sistemi ekseninde bir analiz. R\&S- Research Studies Anatolia Journal, 3 (3), 199-210. https://doi.org/10.33723/rs.733072

Doğan, K. (2020). Max Weber'de Patrimonyalizm ve bürokrasi kavramları: Antik ve Çin imparatorluğu üzerine analizler. Kafkas Üniversitesi İktisadi ve İdari Bilimler Fakültesi Dergisi, 11(21) , 410-433. https://doi.org/10.36543/kauiibfd.2020.019

Downs, A. (2016). Büroların yaşam döngüsü. J.M. Shafritz ve A.C. Hyde. (Eds.). Kamu Yönetimi Klasikleri. (Translation: M. Kara), Global Politika ve Strateji Yayınları.

Dursun, D. (1992). Bürokrasi teorisi ve yönetim. Journal of Social Policy Conferences, O(37-38), 133-149.

Eryılmaz, B. (2016). Kaти yönetimi düşünceler-fonksiyonlar-politikalar (9th ed.). Umuttepe Yayınları.

Farabi. (2017). Ídeal devlet, Hasan Ali Yücel Klasikler Dizisi. (Translation: A. Arslan) Türkiye İş Bankası Kültür Yayınları.

Hacib. Yusuf. H. (2017). Kutadgu Bilig, Hasan Ali Yücel Klasikler Dizisi. (Translation: A. Çakan) Türkiye İş Bankası Kültür Yayınları.

Haldun, İbn. (2016). İbn Haldun ve Mukaddime. Kollektif, Yason Yayınevi.

Heper, M. (1996). Bürokrasi. Cumhuriyet Dönemi Türkiye Ansiklopedisi. (2nd ed.). İletişim Yayınları.

Hindle, T. (2014). Yönetimde çı̆̆ır açan fikirler ve gurular. (Translation: Şensoy, Ü.). Türkiye İş Bankası Kültür Yayınları.

Hughes, O.E (2014). Кати işletmeciliği ve yönetimi. (Translation: Kalkan, B., Akın, B., Akın, Ş). BigBang Yayınları.

İzci, F, Atmaca, Y and Yılmaz, V. (2019). Kamu kurumlarında itibar yönetimi: Kurumsal itibarı ölçme ve değerlendirme. Avrasya Sosyal ve Ekonomi Araştırmaları Dergisi, 6 (7), 302-316.

İzci, F., Atmaca, Y. and Telsaç, C. (2020). Yeni kamu yönetimi anlayışı kapsamında kamu hizmet algısının ölçümü: Van Eğitim ve Araştırma Hastanesi örneği. Bitlis Eren Üniversitesi İktisadi ve İdari Bilimler Fakültesi Akademik İzdüşüm Dergisi, 5(2), 70-88.

Kindî. (2013). Illk felsefe üzerine, (fi'l-felsefeti 'l-ûlâ). in Kindî Felsefi Risaleler (Translation: M. Kaya), Klasik Yayınları.

Kocakula, Ö. (2020). Yönetim ve dinin Lacancı psikanalizi. Urzeni Yayınevi.

Kurt, Y. (2018). Koçi Bey risalesi. (Translation: Y. Kurt). Akçağ Yayınları.

Maverdi (2019). Yönetimin esasları. İlke Yayıncılık. 
Mccormick, J. P. (2015). Weber, Habermas ve Avrupa devletlerinin dönüşümü. İş Bankası Yayınları.

Mecek, M. and Kocakula, Ö. (2020). Yönetim-idare kavramlarının yapısal işlevsel analizi ve kavramsal açıdan tanımlanmas1. Journal of Social and Humanities Sciences Research, 7(54), 1411-1425.

Merton, R. K. (2016). Bürokratik yapı ve kişilik., J.M. Shafritz ve A.C. Hyde. (Eds). Kamu Yönetimi Klasikleri. (Translation: A. Duman). Global Politika ve Strateji Yayınları, 127-141.

Özçınar, M. F. (2020). Yusuf Has Hacib ve Kınalızade Ali Efendi'de '’mürüvvet'” erdemi ve yöneticilik. M. Akıncı, G. N. Şafak. (Eds.). Türk İslam Siyasi Düşüncesi. Kadim Yayınları, 307-321.

Özer, A. and Önen, S.M. (2017). 200 soruda yönetim kamu yönetimi. Gazi Kitapevi.

Öztaş, N. (2015). Yönetim (3rd ed.). Otorite Yayınları.

Rüşd, İbn. (2011). Kurtubalı İbn Rüşd' ün Platon'un devletine düştüğü şerh. (Translation: M. H. Özev). Bordo Siyah Yayınları.

Şeyzeri, Ebün-N. (2013). Nehcü's-sülük fi siyaseti'l- mülük. (Translation: N.M. Emin Efendi). Büyüyen Ay Yayınlar1.

Telsaç, C. (2018). Toplam kalite yönetimine işletmeler açısından bakmak, Uluslararası Akademik Birikim Dergisi, 1(1), 26-34.

Telsaç, C. (2019). Toplam kalite yönetimine kamu yönetimi perspektifinden bakmak, Uluslararası Akademik Birikim Dergisi, 2(1), 14-23.

Telsaç, C. (2020). Yeni kamu yönetimi anlayışı kapsamında kamu hizmet algısının ölçümü: Van Eğitim ve Araştırma Hastanesi örneği [Unpublished Master's Dissertation]. Yüzüncü Yıl Üniversitesi.

Tortop, N., İsbir, E.G., Aykaç, B., Yayman, H. and Özer, M.A. (2016). Yönetim bilimi (10th ed.). Nobel Yayınları.

Weber, M. (1987). Sosyoloji yazıları. (H.H. Gerth and C.W. Mills), (Translation: T. Parla), Hürriyet Vakfı Yayınları.

Weber, M. (2014). Bürokrasi ve otorite (wirtschaft und gesellschaft). (Translation: H.B. Akın), Adres Yayınları.

Weber, M. (2016). Bürokrasi., J. M. Shafritz and A. C. Hyde. (Eds.). Kamu Yönetimi Klasikleri. (Translation: S. Zengin), Global Politika ve Strateji Yayınları.

Weber, M. (2018). Bürokrasi ve otorite. (Translation: Akın, B.), Adres Yayınları.

Yazar, N. (2020). Gazzali'nin Nasihatü'l-Mülük adlı eserinde hükümdarlık teorisi. M. Akıncı, G. N. Şafak (Eds.). Türk Íslam Siyasi Düşüncesi. Kadim Yayınları, 225-239.

Yılmaz, V. and Efșan, N. Ç. (2019). Yerel Kalkınma Aktörlerinin Yerel Kalkınma Yaklaşımı Perspektifinde İncelenmesi. Research Studies Anatolia Journal, 2(7), 342-359 https://doi.org/10.33723/rs.620809 